ISSN: 2146-3042

DOI: $10.25095 /$ mufad.710374

\title{
Finansal Varlıkların Fiyatlandırılmasında Etkinlik Skorlarının Rolü: BİST Sınai Endeks Uygulaması*
}

\author{
Emrah BALKAN** \\ Hakan AYGÖREN***
}

\section{ÖZET}

Bu çalışmada finansal varlıkların fiyatlandırılmasında etkinlik skorlarının rolünün incelenmesi amaçlanmıştır. Bu amaçla büyüklük ve DD/PD (Defter Değeri/Piyasa Değeri) oranı yanında etkinlik skorlarının hisse senedi getirileri üzerindeki etkisi sanayi firmaları özelinde incelenmiştir. Bu yüzden Borsa İstanbul(BíST) Sinai Endekste bulunan firmalara ait veriler kullanılmıştır. Sermaye Varlıklarını Fiyatlama Modeli (SVFM), Fama-French ü̧̧ faktörlü model ve etkinlik skorlarının Fama-French ü̧̧ faktörlü modele eklenmesiyle elde edilerek oluşturulan dört faktörlü model kullanılarak elde edilen zaman serisi regresyon sonuçları karşılaştırllmıştır. Böylece etkinlik skorlarının sanayi firmalarına ait hisse senedi getirilerini açıklamadaki rolü incelenmişstir. Yapılan analizler bu çalışmada kullanılan ü̧̧ modelin sanayi sektöründe yer alan şirketler için geçerli olduğunu göstermiştir. Bununla birlikte bu çallş̧ada yapılan testler dört faktörlü modelin verilere diğer modellerden daha uygun olduğunu göstermiştir.

Anahtar Kelimeler: Varlık Fiyatlama, Etkinlik, SVFM, Fama-French Ü̧̧ Faktörlü Model, BİST.

JEL Sınıflandırması: G11, G12.

\section{The Role of Efficiency Scores in Capital Asset Pricing: An Empirical Study on BIST} Industrial Index

\section{ABSTRACT}

In this study it is aimed to examine the role of efficiency scores in capital asset pricing. For this purpose, the effect of efficiency scores, in addition to size and BTM (Book-to-market) ratio, on the returns of the stocks is examined in the case of industrial firms. Therefore, the data of the companies in the BIST Industrial Index is used. Time series regression results which are obtained by Capital Asset Pricing Model (CAPM), Fama-French Three Factor Model and the four factor model, which is obtained by adding efficiency factor to Fama-French Three Factor Model, are compared. Thus, the role of efficiency scores on explaining the returns of stocks that belong to industrial firms is examined. The analyses show that the three models used in this study are valid for the firms that are in the industrial sector. In addition, tests applied in this study show that the four factor model is better fitted to data than other models.

Keywords: Asset Pricing, Efficiency, CAPM, Fama-French Three Factor Model, BIST.

Jel Classification: $G 11$, G12.

\footnotetext{
* Bu çalışma “Finansal Varlıkların Fiyatlandırılmasında Etkinlik Skorlarının Rolü” isimli doktora tezinden üretilmiştir.

Makale Gönderim Tarihi: 22.08.2019, Makale Kabul Tarihi: 02.09.2019, Makale Türü: Araştırma Makalesi ** Dr., Güney Ege Kalkınma Ajansı, Uzman, balkanemrah@gmail.com, Orcid ID: 0000-0001-7087-668X

*** Prof. Dr., Pamukkale Üniversitesi, İktisadi ve İdari Bilimler Fakültesi, haygoren@pau.edu.tr, Orcid ID: 00000001-5502-4040.
} 


\section{GİRIŞ}

Üretimde kullanılan kaynakların en uygun duruma ne kadar yakın bir şekilde kullanıldığını ifade eden etkinliğin üretim birimi açısından önemi yadsınamaz iken yatırımcılar tarafından ne şekilde değerlendirildiği ya da değerlendirilmesi gerektiği araştırılması gereken bir konu olarak karşımıza çıkmaktadır.

Modern portföy teorisinin Markowitz (1952) tarafından ortaya konmasından sonra finansal varlıkların riskleri ile beklenen getirileri arasındaki ilişkiyi ortaya koymayı amaçlayan çok sayıda model geliştirilmiştir. Bu modellerden Sermaye Varlıklarını Fiyatlama Modeli (SVFM) gördüğü ilgi açısından değerlendirildiğinde finans literatüründe geniş bir yere sahiptir. Sharpe (1964), Lintner (1965) ve Mossin (1966) tarafindan birbirlerinden bağımsız olarak geliştirilen SVFM hala yaygın bir şekilde kullanılmasına rağmen varsayımlarının gerçekçi bulunmamasından ötürü çeşitli eleştirilere maruz kalmıştır. Bu sebeple modelin geliştirilmesine yönelik adımlar atılmış ve yeni modeller oluşturulması gündeme gelmiştir. Oluşturulan yeni modellere önemli bir örnek de Fama ve French (1993) tarafından geliştirilen üç faktörlü varlık fiyatlandırma modelidir.

Carhart (1997), Pastor ve Stambaugh (2003), Chan ve Faff (2005), Rahim ve Nor (2006), Ammann ve Steiner (2008), Nguyen ve Swanson (2009), Nguyen ve Puri (2009), Ünlü(2013), Fama ve French (2015) ise Fama-French üç faktörlü modele farklı faktörler ekleyerek oluşturulan modelleri analizlerinde kullanmışlardır. Görüldügüü üzere Fama-French üç faktörlü modele yeni faktörler ekleyerek oluşturulan modeller ile finansal varlıkların fiyatlandırılmasında ek faktörlerin rolü incelenmiş, bunun yanında oluşturulan yeni modellerin varlık fiyatlarını açıklama kabiliyetini artırıp artırmadığı incelenmiştir. Bu çalışmada ise Fama-French üç faktörlü modele etkinlik faktörü eklenerek elde edilen model ile etkinlik skorlarının sanayi firmalarına ait hisse senedi getirileri üzerindeki etkisi sorgulanmıştır. Etkinlik hesaplamasının sektör özelinde yapılması gerekliliğinden hareketle Borsa İstanbul'un en geniş sektör endeksi olan sınai endeksteki firmalar incelenmiştir.

Çalışmanın temel hipotezi yüksek etkinlik skorlarına sahip firma grubu ile düşük etkinlik skorlarına sahip firma grubu arasındaki getiri farkının sanayi firmaları hisse senedi getirilerini etkileyen bir faktör olduğudur. Oluşturulan model Sermaye Varlıklarını Fiyatlama Modeli ve Fama French Üç Faktörlü Varlık Fiyatlandırma Modeli ile karşılaştırılmış, etkinlik skorlarının modelin getirileri açıklama kabiliyetini artırıp artırmadı $\breve{g} 1$ incelenmiştir. Çalışmanın sonraki bölümlerinde ilk olarak konu ile ilgili literatürde yer alan çalışmalar özetlenmiş, sonrasında kullanılan veri ve metodoloji anlatılmıştır. Analiz bulgularının sıralanmasından sonra sonuç bölümüne yer verilmiştir.

\section{LITERATÜR ARAŞTIRMASI}

$\mathrm{Bu}$ bölümde finansal varlıkların fiyatlandırılmasını içeren çalışmalara ve firma etkinliğine yönelik çalışmalara ayrı ayrı yer verilmiştir.

\subsection{Finansal Varlıkların Fiyatlandırılması ile İlgili Literatür Araştırması}

Finans literatüründe hisse senedi getirilerini açıklama amacıyla yaygın olarak kullanılan SVFM'nin bir çok durumda yetersiz kalması nedeniyle farklı faktörlerin de dahil olduğu alternatif modeller araştırılmıştır. Fama ve French (1993) tarafından ortaya atılan ve Fama ve French (1996) tarafından geliştirilen modele göre, bir portföyün risksiz faiz oranı üzerindeki getirisi şu üç faktöre bağlıdır: (i) Pazar porföyünün risksiz faiz oranı üzerindeki 
getirisi $\left(\mathrm{RM}_{t}-\mathrm{RF}_{\mathrm{t}}\right.$ ), (ii) Piyasa değeri küçük olan hisse senetlerinden oluşan portföyün getirisi ile piyasa değeri büyük olan hisse senetlerinden oluşan portföyün getirisi arasındaki fark (SMB), (iii) DD/PD oranı yüksek olan hisse senetlerinden oluşan portföyün getirisi ile $\mathrm{DD} / \mathrm{PD}$ oranı düşük olan hisse senetlerinden oluşan portföyün getirisi arasındaki fark (HML).

Fama-French üç faktörlü varlık fiyatlandırma modelinin oluşumundan sonra FamaFrench üç faktörlü varlık fiyatlandırma modeline farklı faktörler eklenerek model geliştirilmeye çalışılmışıtır. Bu kapsamda yapılan çalışmalar Tablo 1'de özetlenmektedir.

Tablo 1. Fama-French Üç Faktörlü Varlık Fiyatlandırma Modeline Farklı Faktörler Eklenen Çalışmalar

\begin{tabular}{|c|c|c|c|c|}
\hline Yazarlar & Dönem & Borsa & Faktörler & Sonuçlar \\
\hline $\begin{array}{l}\text { Carhart } \\
(1997)\end{array}$ & $\begin{array}{l}\text { Ocak 1962- } \\
\text { Aralık } 1993\end{array}$ & $\begin{array}{l}\text { NYSE, } \\
\text { AMEX, } \\
\text { NASDAQ }\end{array}$ & $\begin{array}{l}(\mathrm{RM}-\mathrm{RF}), \mathrm{SMB}, \mathrm{HML} \\
\text { momentum faktörü. }\end{array}$ & $\begin{array}{l}\text { Çalışma, dört faktör modelinin hisse senedi getirilerini } \\
\text { açıklamada kullanılabileceğini öne sürmektedir. }\end{array}$ \\
\hline $\begin{array}{l}\text { Pastor ve } \\
\text { Stambaugh } \\
(2003)\end{array}$ & 1966-1999 & $\begin{array}{l}\text { NYSE, } \\
\text { AMEX }\end{array}$ & $\begin{array}{l}\text { (RM - RF), SMB, HML, } \\
\text { momentum faktörü, } \\
\text { likidite faktörü. }\end{array}$ & $\begin{array}{l}\text { Analiz sonucunda likiditenin hisse senedi fiyatlamasında } \\
\text { önemli bir değişken olduğu ifade edilmiştir. }\end{array}$ \\
\hline $\begin{array}{l}\text { Chan ve Faff } \\
(2005)\end{array}$ & $\begin{array}{l}\text { Ocak 1989- } \\
\text { Aralık } 1998\end{array}$ & $\begin{array}{l}\text { Avustralya } \\
\text { Borsas1 }\end{array}$ & $\begin{array}{l}(\mathrm{RM}-\mathrm{RF}), \mathrm{SMB}, \mathrm{HML}, \\
\text { likidite faktörü. }\end{array}$ & $\begin{array}{l}\text { Likidite ölçütü olarak hisse devir oranının kullanıldığı } \\
\text { çalışmada, hisse devir oranını içeren dört faktörlü modele } \\
\text { yönelik güçlü kanıtlar ortaya çımıştır. }\end{array}$ \\
\hline $\begin{array}{l}\text { Rahim ve Nor } \\
(2006)\end{array}$ & $\begin{array}{l}\text { Ocak 1987- } \\
\text { Aralık } 2000\end{array}$ & $\begin{array}{l}\text { Malezya } \\
\text { Borsası }\end{array}$ & $\begin{array}{l}(\mathrm{RM}-\mathrm{RF}), \mathrm{SMB}, \mathrm{HML}, \\
\text { likidite faktörü. }\end{array}$ & $\begin{array}{l}\text { Varlık fiyatlama modellerinde likiditenin rolünü destekleyen } \\
\text { bulgulara ulaşılmıştır. }\end{array}$ \\
\hline $\begin{array}{l}\text { Ammann ve } \\
\text { Steiner (2008) }\end{array}$ & $\begin{array}{l}\text { Ocak 1990- } \\
\text { Aralık } 2005\end{array}$ & $\begin{array}{l}\text { İsviçre } \\
\text { Borsası }\end{array}$ & $\begin{array}{l}(\mathrm{RM}-\mathrm{RF}), \mathrm{SMB}, \mathrm{HML} \\
\text { momentum faktörü. }\end{array}$ & $\begin{array}{l}\text { Çalışmada kullanılan faktörlerin açıklayıcı gücü yüksek } \\
\text { olarak tespit edilmiştir. Böylece modelin İsviçre borsası için } \\
\text { uygun olduğu sonucuna ulaşılmıştır. }\end{array}$ \\
\hline $\begin{array}{l}\text { Nguyen ve } \\
\text { Swanson } \\
(2009)\end{array}$ & $\begin{array}{l}\text { Temmuz 1980- } \\
\text { Haziran } 2002\end{array}$ & $\begin{array}{l}\text { NYSE, } \\
\text { AMEX, } \\
\text { NASDAQ }\end{array}$ & $\begin{array}{l}(\mathrm{RM}-\mathrm{RF}), \mathrm{SMB}, \mathrm{HML} \\
\text { momentum faktörü. }\end{array}$ & $\begin{array}{l}\text { Çalışmada yüksek etkinliğe sahip firmalardan oluşan } \\
\text { portföyün düşük etkinliğe sahip firmalardan oluşan portföye } \\
\text { göre daha düşük performans gösterdiği sonucuna } \\
\text { ulaşılmıştır. Ayrıca, firma etkinliğinin ortalama getirileri } \\
\text { açıklama konusunda yatay kesit analizinde güçlü olduğu } \\
\text { belirtilmiştir. }\end{array}$ \\
\hline $\begin{array}{l}\text { Nguyen ve } \\
\text { Puri (2009) }\end{array}$ & $1963-2004$ & $\begin{array}{l}\text { NYSE, } \\
\text { AMEX. }\end{array}$ & $\begin{array}{l}(\mathrm{RM}-\mathrm{RF}), \mathrm{SMB}, \mathrm{HML}, \\
\text { likidite faktörü. }\end{array}$ & $\begin{array}{l}\text { Likidite faktörünün hisse özelinde likidite seviyesini } \\
\text { yansıtmadığı sonucuna ulaşılmıştır. }\end{array}$ \\
\hline Ünlü (2013) & $\begin{array}{l}\text { Temmuz } 1992- \\
\text { Haziran } 2011\end{array}$ & BİST & $\begin{array}{l}\text { (RM - RF), SMB, HML, } \\
\text { momentum faktörü, } \\
\text { Likidite faktörü. }\end{array}$ & Tüm modellerin BİST için geçerli olduğu tespit edilmiştir. \\
\hline $\begin{array}{l}\text { Fama ve } \\
\text { French (2015) }\end{array}$ & $\begin{array}{l}\text { Temmuz } 1963- \\
\text { Aralık } 2013\end{array}$ & $\begin{array}{l}\text { NYSE, } \\
\text { AMEX, } \\
\text { NASDAQ }\end{array}$ & $\begin{array}{l}(\mathrm{RM}-\mathrm{RF}), \mathrm{SMB}, \mathrm{HML}, \\
\text { karlılık faktörü, yatırım } \\
\text { faktörü. }\end{array}$ & $\begin{array}{l}\text { Beş faktörlü model Fama-French üç faktörlü modelden daha } \\
\text { iyi performans göstermiştir. }\end{array}$ \\
\hline
\end{tabular}

\subsection{Firma Etkinliği ile İlgili Literatür Araştırması}

Etkinlik çalışmaları hastane, üniversite, tarlalar, kamu kurumları, bankalar, aracı kurumlar ve firmalar gibi farklı unsurların değerlendirilmesinde kullanılmaktadır. Etkinliğin hesaplanmasında bir girdi-çıktı ilişkisi kurulması ihtiyacı bulunmaktadır. Bu sebeple hangi unsurların girdi ya da çıktı olarak seçileceğinin belirlenmesi gerekmektedir. Bu yüzden firma etkinliği üzerine yapılan çalışmalarda kullanılan girdi ve çıktı değişkenleri önem arz etmektedir. Literatürde etkinlik değerlerinin hesaplanmasında Veri Zarflama Analizi (VZA) veya Stokastik Sınır Analizi (SSA) kullanıldığı görülmüştür. Firma etkinliği üzerine yapılan çalışmalar ve bu çalışmalarda kullanılan girdi-çıktı bileşenleri Tablo 2'de sunulmaktadır. 
Tablo 2. Firma Etkinliği İle İlgili Çalışmalar.

\begin{tabular}{|c|c|c|c|c|}
\hline Yazarlar & $\begin{array}{l}\text { Analiz Metodu } \\
\text { /Dönemi }\end{array}$ & Firmalar & Girdiler ve Çıktılar & Sonuç \\
\hline $\begin{array}{l}\text { Ulucan } \\
(2002)\end{array}$ & VZA/2000 y1lı & $\begin{array}{l}2000 \text { 'de İSO } 500 \text { 'de ve } \\
\text { BİST'te bulunan } 103 \\
\text { şirket. }\end{array}$ & $\begin{array}{l}\text { Girdiler: Çalışan sayısı, aktifler } \\
\text { ve özsermaye. } \\
\text { Çıktılar: Satışlar ve kar, piyasa } \\
\text { değeri, getiri ve hisse başına kar. }\end{array}$ & $\begin{array}{l}\text { Üç ayrı çıktı grubu için sırasıyla } 42,19 \\
\text { ve } 45 \text { karar verme birimi ölçek etkin } \\
\text { bulunmuştur. }\end{array}$ \\
\hline $\begin{array}{l}\text { Bakirc1 } \\
(2006)\end{array}$ & $\begin{array}{l}\text { VZA/1999 ve } \\
2004\end{array}$ & $\begin{array}{l}\text { Türkiye'de otomotiv } \\
\text { sektöründe bulunan } 13 \\
\text { firma. }\end{array}$ & $\begin{array}{l}\text { Girdiler: Net aktifler, öz } \\
\text { sermaye ve çalışan işçi sayısı. } \\
\text { Çıktılar: Net satışlar, vergi } \\
\text { öncesi kar ve ihracat değerleri. }\end{array}$ & $\begin{array}{l}\text { On üç firma arasında altı firmanın } \\
\text { girdilerde etkin olamadığı belirlenirken, } \\
\text { küçük ölçekli firmaların daha etkin } \\
\text { oldukları sonucuna ulaşılmıştır. }\end{array}$ \\
\hline $\begin{array}{l}\text { Bayyurt ve } \\
\text { Sagbansua } \\
(2007)\end{array}$ & $\mathrm{VZA} / 2002$ & $\begin{array}{l}2002 \text { yılında imalat } \\
\text { sanayi firmaları içinde } \\
\text { ilk } 1000 \text { 'de yer alan } 11 \\
\text { çimento firması. }\end{array}$ & $\begin{array}{l}\text { Girdiler: Cari oran, kaldıraç } \\
\text { oranı, stok devir hızı, makine- } \\
\text { tesis-cihazlar, özsermaye ve } \\
\text { nakit akım oranı } \\
\text { Çıktılar: Karlılık, verimlilik ve } \\
\text { borsa getirisi }\end{array}$ & $\begin{array}{l}5 \text { firmanın etkinlik skorları } 1 \text { 'in altında } \\
\text { çıkmıştır. }\end{array}$ \\
\hline $\begin{array}{l}\text { Ertuğrul ve } \\
\text { Tuş Işık } \\
(2008)\end{array}$ & VZA/2003-2007 & $\begin{array}{l}\text { İMKB } 100 \text { endeksinde } \\
\text { bulunan ve metal ana } \\
\text { sanayi sektöründeki } 13 \\
\text { işletme. }\end{array}$ & $\begin{array}{l}\text { Girdiler: Aktifler ve özsermaye. } \\
\text { Çıktılar: Net satışlar ve net kar } \\
\text { tutarları. }\end{array}$ & $\begin{array}{l}13 \text { firmanın yıllara göre etkinlik skorları } \\
\text { ve potansiyel iyileştirme oranları elde } \\
\text { edilmiştir. }\end{array}$ \\
\hline $\begin{array}{l}\text { Kayalı } \\
(2009)\end{array}$ & VZA/2007 & $\begin{array}{l}\text { Türkiye'nin en büyük } \\
500 \text { şirketi arasında yer } \\
\text { alan tekstil ürünleri } \\
\text { şirketleri. }\end{array}$ & $\begin{array}{l}\text { Girdiler: çalışan sayısı, } \\
\text { özsermaye, aktif toplamı. } \\
\text { Çıktılar: Net satışlar ve net kar. }\end{array}$ & $\begin{array}{l}29 \text { firmanın ortalama teknik etkinliğ } \mathrm{i} \\
0,566 \text {, ortalama saf teknik etkinliği } 0,657 \\
\text { ve ortalama ölçek etkinliği } 0,872 \\
\text { bulunmuştur. }\end{array}$ \\
\hline $\begin{array}{l}\text { Aygören } \\
\text { ve } \\
\text { Yeşilyurt } \\
\text { (2011) }\end{array}$ & SSA/2005-2008 & $\begin{array}{l}\text { Türkiye'de faaliyet } \\
\text { gösteren } 78 \text { arac1 } \\
\text { kurum. }\end{array}$ & $\begin{array}{l}\text { Girdiler: Özsermaye, satışların } \\
\text { maliyeti ve faaliyet giderleri. } \\
\text { Çıktı: Toplam gelirler. }\end{array}$ & $\begin{array}{l}\text { Aracı kurumun yaşı ve çalışan sayısının } \\
\text { etkinlik üzerinde olumlu etkiye sahip } \\
\text { olduğu, şube sayısı, aracı kurum } \\
\text { büyüklüğü, finansal kaldıraç ve hizmet } \\
\text { rasyosunun etkinliği olumsuz etkilediği } \\
\text { ortaya çımıştır. }\end{array}$ \\
\hline $\begin{array}{l}\text { Akyüz vd. } \\
(2013)\end{array}$ & $\begin{array}{c}\text { VZA ve } \\
\text { Malmquist } \\
\text { Toplam Faktör } \\
\text { Verimlilik } \\
\text { Endeksi Yöntemi/ } \\
\text { 2007-2011 } \\
\end{array}$ & $\begin{array}{l}\text { BİST'te işlem gören } 11 \\
\text { mevduat bankası. }\end{array}$ & $\begin{array}{l}\text { Girdiler: Mevduat, özsermaye, } \\
\text { faiz giderleri. } \\
\text { Çıktılar: Net kar ve faiz gelirleri }\end{array}$ & $\begin{array}{l}\text { Malmquist Toplam Faktör } \\
\text { Verimliliğindeki Değişim endeksi 2008- } \\
2009 \text { döneminde artış, diğer dönemlerde } \\
\text { bir azalma göstermiştir. }\end{array}$ \\
\hline $\begin{array}{l}\text { Castiglione } \\
\text { ve Infante } \\
(2014)\end{array}$ & SSA/1995-2006 & İtalyan imalat firmaları & $\begin{array}{l}\text { Girdiler: Bilgi ve iletişim } \\
\text { teknolojileri sermayesi, bilgi ve } \\
\text { iletişim teknolojisi ile ilgisi } \\
\text { olmayan sermaye, eğitimi } \\
\text { yüksek işçi sayısı, düşük eğitimli } \\
\text { işçi sayısı ve hammadde } \\
\text { Çıktı: Satış gelirleri } \\
\end{array}$ & $\begin{array}{l}\text { Bilgi ve iletişim teknolojilerinin teknik } \\
\text { etkinlik üzerindeki getirilerinin firmaya } \\
\text { özgü değişkenler olan yönetim } \\
\text { uygulamaları, iş gücü organizasyonu ve } \\
\text { ar-ge'den etkilendiği sonucuna } \\
\text { ulaşılmıştır }\end{array}$ \\
\hline $\begin{array}{l}\text { Özdağoğlu } \\
(2015)\end{array}$ & VZA/2014 y1lı & $\begin{array}{l}\text { 2014'te BİST bilişim } \\
\text { endeksinde yer alan on } \\
\text { iki şirket. }\end{array}$ & $\begin{array}{l}\text { Girdiler: Hazır değerler, stoklar, } \\
\text { maddi duran varlıklar ve } \\
\text { özsermaye } \\
\text { Çıktılar: Brüt satışlar ve vergi } \\
\text { öncesi kar. }\end{array}$ & $\begin{array}{l}\text { Brüt satışları yüksek olan bazı firmaların } \\
\text { aslında etkin olmadıkları, sektör } \\
\text { ortalamasına göre küçük sayılabilecek } \\
\text { bazı firmaların ise oldukça etkin firmalar } \\
\text { oldukları tespit edilmiştir. }\end{array}$ \\
\hline
\end{tabular}

\section{VERİ VE METODOLOJI}

$\mathrm{Bu}$ çalışmada yatırımcıların yatırım aşamasında firmaların etkinliğini değerlendirdikleri varsayılmış ve bu varsayımdan hareketle etkinlik, bir faktör olarak incelemeye alınmıştır. Bu bağlamda, firma etkinlik düzeyini temsil eden etkinlik skorlarının varlık fiyatlamadaki rolünü incelemek amacıyla Fama French Üç Faktörlü Model'e etkinlik faktörü eklenerek yeni bir model elde edilmiştir. Varlık fiyatlandırmasında etkinliğin rolü, New York Borsası hisse senetleri için Nguyen ve Swanson (2009) tarafindan incelenmiştir. Fakat Nguyen ve Swanson (2009) portföylerin verimlilik seviyeleri ile hisse senedi 
performansı arasındaki bağlantıyı incelemek için literatürde mevcut modelleri kullanırken, bu çalışma mevcut bir modeli kullanmak yerine yeni bir model oluşturarak etkinliği model içerisinde bir risk faktörü olarak ele almış olup, bu açıdan Nguyen ve Swanson'dan (2009) farklılaşmaktadır.

Çalışmada, etkinlik skorlarının sanayi firmaları portföyleri getirileri üzerindeki etkisi incelenmek istendiğinden öncelikle modeller oluşturulmuştur. İlk olarak SVFM, Fama-French Üç Faktörlü Model ve etkinlik skoru faktörünün eklendiği dört faktörlü model oluşturulmuştur. Sonraki aşamada, karar verme birimi olarak seçilen 109 firmanın etkinlik skorları stokastik sınır analizi yöntemiyle hesaplanmıştır.

Araştırmaya konu olan hisse senetlerinin 2005 Temmuz-2015 Haziran dönemi aylık getiri verileri için Borsa İstanbul internet sitesinden alınan düzeltilmiş aylık hisse senedi fiyatlarından elde edilen aylık yüzde değişim verileri ve Finnet Active Charts programı kullanılarak www.finnet.com.tr veri tabanından temin edilen düzeltilmiş aylık hisse senedi fiyatlarından elde edilen aylık yüzde değişim verileri kullanılmışır. Bir veri kaynağı üzerinden elde edilemeyen getiri verisi için diğer kaynak kullanılmış olup, iki kaynaktan da elde edilebilen getiri verilerinin birbiriyle tutarlı olduğu görülmüştür.

Risksiz faiz oranını temsil etmesi için, Hazine Müsteşarlığı resmi internet sitesinde ${ }^{1}$ istatistikler bölümünde bulunan iç borçlanmanın aylık ortalama maliyeti (Sabit faizli) yıllık bileşik faiz oranı verileri aylık değerlere aşağıdaki şekilde dönüştürülerek kullanılmıştır.

$$
\mathrm{R}_{\mathrm{ft}}=\left(\mathrm{R}_{\mathrm{ht}}+1\right)^{1 / 12}-1
$$

$\mathrm{R}_{\mathrm{ht}}: \mathrm{t}$ ayındaki iç borçlanmanın aylık ortalama maliyeti (Sabit faizli) yıllık bileşik faiz oran1

Rft: $t$ ayındaki iç borçlanmanın aylık ortalama maliyeti (Sabit faizli)

Pazar portföyünü temsil etmek üzere Borsa İstanbul internet sitesinden elde edilen BIST Tüm Endeksi aylık yüzde değişimi verileri kullanılmıştır.

Etkinlik skorlarının hesaplanmasında firmaların 2004-2013 dönemini kapsayan 10 yıllık satı̧ gelirleri, satışların maliyeti, faaliyet giderleri ve özsermaye verileri kullanılmış olup, söz konusu veriler Finnet Mali Analiz Programı kullanılarak elde edilmiştir.

Oluşturulacak portföylerin sınıflandırılması ve firma büyüklüğü ile ilgili faktör olan SMB faktörünün hesaplanması amacıyla kullanılan firma büyüklüğünü temsil etmesi için Fama ve French'in $(1993,1996)$ yaptığı gibi piyasa değeri kullanılmıştır. Örnekleme dahil edilen firmaların her yılın Haziran ayı piyasa değerlerine ait veriler ve HML faktörünün elde edilmesinde kullanılmak üzere, çalı̧̧maya konu hisse senetlerinin ait olduğu şirketlerin defter değerleri piyasa değerlerine bölünerek elde edilen DD/PD oranları Finnet Mali Analiz Programı kullanılarak elde edilmiştir.

Daha sonra analizi yapılacak modellerde ve faktörlerin oluşturulmasında kullanmak için portföyler ve kesişim portföyleri oluşturularak bu portföylerin getirileri hesaplanmıştır.

\footnotetext{
${ }^{1}$ Hazine Müsteşarlığı resmi internet sitesi: www.hazine.gov.tr
} 
Faktörlerin oluşturulması ve faktör getirilerinin hesaplanması akabinde ise zaman serisi regresyonları yapılmışıı. Çalışmaya konu modellerdeki kesişim katsayılarının istatistiksel olarak anlamlı bir şekilde sıfirdan farklı olup olmadıklarını test etmek için GRS-F testi kullanılmıştır.

\subsection{SVFM, Fama French Üç Faktörlü Model ve Etkinlik Skoru Faktörünün Eklendiği Dört Faktörlü Modelin Oluşturulması}

Sermaye varlıkları fiyatlama modeline göre bir portföyün getirisi, paranın zaman değerine yani risksiz faiz oranına, sistematik riske katlanmanın karşılığı olan piyasa risk primine ve sistematik risk miktarına bağlıdır (Ross, vd., 2012: 436). Bu nedenle, CAPM'nin zaman serisi regresyon analizinde Eşitlik 2 kullanılmıştır.

Diğer çalışmalardan farklı olarak etkinlik skorlarının varlık fiyatlama üzerindeki rolü incelenmek istendiği için dört faktörlü modeli oluştururken Fama-French üç faktör modeline yeni faktörlerin eklendiği çalışmalardan ilham alınmıştır. Etkinlik skorları primini ifade eden dördüncü faktör, çalışmaya konu hisse senetlerinin yıl sonu etkinlik skorlarına göre sıralanması ve medyan değerinden iki gruba ayrılarak, etkinlik skoru medyan değerden büyük veya eşit olan hisselerden oluşan portföy getirisi ile etkinlik skoru medyan değerden küçük hisselerden oluşan portföyün getirisi arasındaki farkı olarak belirlenmiştir. Bu yeni faktörün hesaplanma şekli bu çalışmanın sonraki bölümlerinde gösterilmiştir. Etkinlik skorlarının BİST Sınai Endeks'te bulunan sanayi firmalarının getirilerine olan etkisini incelemek amaciyla Fama-French üç faktörlü modele EMI (Efficient minus inefficient) adı verilen etkinlik faktörünü de ekleyerek zaman serisi regresyonu yaklaşımı içinde dört faktörlü model oluşturulmuştur. Sonuç olarak, zaman serisi regresyonlarının analizinde kullanılmış olan üç model aşağıdaki formlarda belirlenmiş̧ir.

SVFM:

$$
\mathrm{R}_{\mathrm{it}}-\mathrm{RF}_{\mathrm{t}}=\alpha_{\mathrm{i}}+\beta_{\mathrm{i}}\left[\mathrm{RM}_{\mathrm{t}}-\mathrm{RF}_{\mathrm{t}}\right]+\mathrm{e}_{\mathrm{it}}
$$

Fama-French Üç Faktörlü Model:

$$
\mathrm{R}_{\mathrm{it}}-\mathrm{RF}_{\mathrm{t}}=\alpha_{\mathrm{i}}+\beta_{\mathrm{i}}\left[\mathrm{RM}_{\mathrm{t}}-\mathrm{RF}_{\mathrm{t}}\right]+\mathrm{siSMB}_{\mathrm{t}}+\mathrm{h}_{\mathrm{i}} \mathrm{HML}_{\mathrm{t}}+\mathrm{e}_{\mathrm{it}}
$$

Dört Faktörlü Model:

$\mathrm{R}_{\mathrm{it}}-\mathrm{RF}_{\mathrm{t}}=\alpha_{\mathrm{it}}+\beta_{\mathrm{i}}\left[\mathrm{RM}_{\mathrm{t}}-\mathrm{RF}_{\mathrm{t}}\right]+\mathrm{siSMB}_{\mathrm{i}}+\mathrm{h}_{\mathrm{i}} \mathrm{HML}_{\mathrm{t}}+\mathrm{f}_{\mathrm{i}} \mathrm{EMI}_{\mathrm{t}}+\mathrm{e}_{\mathrm{it}}$

Rit: i portföyünün t zamanındaki getirisi

$\mathrm{RM}_{\mathrm{t}}$ : Piyasa portföyünün $\mathrm{t}$ zamanındaki getirisi

$\mathrm{RF}_{\mathrm{t}}$ : $\mathrm{t}$ zamanındaki risksiz faiz oranı

SMB: Piyasa değeri küçük hisselerden oluşan portföyün getirisi ile büyük hisselerden oluşan portföyün getirisi arasındaki farkı ifade eden büyüklük primidir (Small minus big). 
HML: DD/PD oranı yüksek hisselerden oluşan portföyün getirisi ile düşük hisselerden oluşan portföyün getirisi arasındaki farkı ifade eden değer primidir (High minus low).

EMI: Etkinliği yüksek hisselerden oluşan portföyün getirisi ile etkinliği düşük hisselerden oluşan portföyün getirisi arasındaki farkı ifade eden etkinlik primidir (Efficient minus inefficient).

eit: Hata terimi

\subsection{Sanayi Firmaları Etkinlik Modelinin Olușturulması ve Etkinlik Skorlarının Hesaplanması}

Etkinlik, girdi ve çıtı miktarları ile herhangi bir sektördeki bir firmanın ulaşabileceği en iyi girdi-çıktı sınırı arasındaki mesafe olarak tanımlanabilir (Daraio ve Simar, 2007: 14). Anlaşılacağı üzere etkinlik hesaplamalarında girdi ve çıktı arasındaki ilişki incelendiğinden girdinin çıktıya dönüşme sürecinin benzer olduğu karar verme birimlerinin seçilmesi gerekmektedir. Yani aynı sektörde bulunan veya benzer iş yapan karar verme birimlerinin seçilmesi gerekmektedir. Dolayısıyla etkinliği ölçülecek grubun ortak bir sektörünün bulunması önemlidir. Bu sebeple bu çalıșmada, Fama-French Üç Faktörlü Model'in veya bu modelin ekstra faktörlü hallerinin kullanıldığı ve borsanın genelinin örnekleme alındığı çalışmalardan farklı olarak tek sektöre yönelik bir analiz yapılmışıtır. Etkinlik skorlarının sanayi sektöründe faaliyet gösteren firmalara ait hisse senedi getirilerindeki rolünün incelenmesi amacıyla BİST’te işlem gören sanayi firmaları kullanılmak istenmiştir. Analizde veri eksikliği nedeniyle etkinlik skoru hesaplanamayan firmalar analize dahil edilmemiştir. $\mathrm{Bu}$ yüzden hem etkinlik skoru hesaplamak için kullanılacak verileri uygun ve mevcut olan hem de diğer faktörleri hesaplamak için kullanılacak verileri uygun ve mevcut olan firmalar analize dahil edilmiştir. Bu sebeple 29.06.2015 tarihinde sınai endekste (XUSIN) yer alan firmalardan 2004-2015 döneminde ihtiyaç duyulan verileri mevcut olan firmalara ait veriler çalışmada kullanılmıştır. Verilerine ulaşılamayan firmalar, herhangi bir dönemde negatif öz sermayeye sahip olan firmalar ve farklı getiri oranları ile tek firmanın eşleşmesi metodoloji açısından uygulanamaz olduğundan grup hisseleri bulunan firmalar analize dahil edilmemiştir. Sonuç olarak etkinlik skorlarının hesaplanmasında 109 firmaya ait veriler kullanılmış ve bunların teknik etkinlik seviyeleri incelenmiştir. Fakat analizin modeller için portföy oluşturma aşamasında, 2005 ve 2006 yılları için 106 firmanın, diğer yıllar için 109 firmanın verileri kullanılmıştır. Bunun sebebi aradaki farka neden olan 3 firmanın 2006 yilında halka arz edilmeleridir.

Etkinlik düzeyinin ölçülmesinde genel olarak kullanılan yöntemler VZA ve SSA olup, SSA'da istatistiksel gürültü teriminin bulunması ve geleneksel hipotez testlerini uygulamak için kullanılabilir bir yöntem olması SSA'yı VZA'ya göre avantajlı duruma getirmektedir. Bununla birlikte, SSA'da etkinsizlik terimi için dağılım şeklinin belirlenmesi gerekliliği ve üretim fonksiyonu için fonksiyonel bir form belirlenmesi gerekliliği uygulanabilirlik kolaylı̆̆ açısından VZA'nın daha avantajlı olduğunu göstermektedir (Coelli vd., 2005: 312). Üretim biriminin elinde olmayan rastgele etkiler ile teknik etkinliğin birbirinden ayrılarak teknik etkinliğin belirlenmesini sağlaması nedeniyle bu çalışmada SSA uygulanmıştır.

Çalışmanın bu kısmındaki amaç örneklemde bulunan firmaların etkinlik skorlarının hesaplanmasıdır. Bunun için üretimi en iyi ifade edecek girdi ve çıktı değişkenlerinin 
seçilmesi gerekmektedir. Yapılacak ölçümün sağl1klı olması için karar verme birimlerine göre girdi ve çıktıların anlamlı olması gerekmektedir. Sanayi firmaları fazla ve farklı ürünler ürettiklerinden üretim sayısını temel almak anlamlı olmayacaktır. Bu nedenle çıktı olarak seçilecek değişkenin üretimi temsil edecek bir değişken olması istenmiş, sonuç olarak satışların çıktıyı temsil edebilecek bir unsur olduğu düşünülerek satış gelirleri çıktı olarak seçilmiştir.

Satışların maliyeti; işletmenin üretip sattığı mamullerin, satılan ticari malların, işletmenin ürettiği hizmetlerin ve diğer satışların maliyetinden oluşmaktadır. Faaliyet giderleri ise satışların maliyetine dahil edilmeyen araştırma ve geliştirme giderleri, pazarlama, satış ve dağıtım giderleri ve genel yönetim giderlerini içermektedir (Sevilengül, 2005: 697-700). Tüm bu giderlerin, çıktı olarak seçilen satış gelirlerine ulaşmak için firmaya girdi olan unsurların maliyeti olduğu düşünüldüğünden üretim sürecinde kullanılan girdilerin bir kısmını temsil etmesi için satışların maliyeti ve faaliyet giderleri seçilmiştir. Sevilengül (2005) öz sermayenin işletmeye sermaye olarak konulan değerler ile işletme çalışmaları sonucu sağlanan ve işletme bünyesinde bulunan dönem karı/zararı, önceki dönem karları/zararları ve yedekler ile sermaye yedekleri gibi kalemlerden oluşmakta olduğunu ve net varliklardan borçların düşülmesi sonucunda da bulunabildiğini belirtmiştir. Yani öz sermaye firmanın varlıklarının borçları haricinde kalan kısmını göstermekte, ödenmiş sermayeyi içermekte ve karlılıktan da doğrudan etkilenmektedir. Bu sebeplerle öz sermaye bir diğer girdi olarak analize dahil edilmiştir.

Uygulamada 10 yıllık panel veri için stokastik sınır analizi modellerinden hata bileşenleri modeli kullanılmıştır. Modelden tahmin edilen parametreler, en çok olabilirlik kestirimleri, gamma değerleri, olabilirlik oranı değerleri ve firmalara ait teknik etkinlik değerleri FRONTIER 4.1 yazılımı ile hesaplanmıştır. Bu çalışma için Radam vd. (2010) çalışmasına benzer şekilde Battese ve Coelli (1992) spesifikasyonunda sunulan hata bileşenleri modeli temel alınmış, fonksiyonel biçim olarak ise Cobb-Douglas üretim fonksiyonu modeli aşağıdaki şekilde oluşturulmuştur.

$\ln \left(\mathrm{SAT}_{\mathrm{it}}\right)=\beta_{0}+\beta_{1} \ln \left(\mathrm{SMM}_{\mathrm{it}}\right)+\beta_{2} \ln \left(\mathrm{FG}_{\mathrm{it}}\right)+\beta_{3} \ln \left(\mathrm{OZS}_{\mathrm{it}}\right)+\mathrm{v}_{\mathrm{it}}-\mathrm{u}_{\mathrm{it}}$

$\mathrm{i}=1,2, \ldots, 109 ; \mathrm{t}=1,2, \ldots, 10$

SAT: Satış gelirlerini ifade etmektedir.

SMM: Satılan malın maliyetini ifade etmektedir.

FG: Faaliyet giderlerini ifade etmektedir.

OZS: Özsermayeyi ifade etmektedir.

Vit: uit'den bağımsız ve iid $\mathrm{N}\left(0, \sigma v^{2}\right)$ olduğu varsayılan tesadüfi değişkenler

uit: Üretimdeki teknik etkinsizliği gösterdiği farz edilen, $N\left(\mu, \sigma u^{2}\right)$ dağılımının sıfırda kesilmiş, birbirinden bağımsız ve olasılık dağılımları aynı olduğu varsayılan ve negatif olmayan tesadüfi değişkenlerdir.

$\mathrm{U}_{\mathrm{it}}=\left(\mathrm{U}_{\mathrm{i}} \exp (-\eta(\mathrm{t}-\mathrm{T}))\right)$ şeklinde hesaplanır. 
$\eta$ : Bilinmeyen ve hesaplanacak olan bir parametredir.

Teknik etkinsizliği ifade eden ui'nin nasıl bir dağılıma sahip olduğunun ve model yapısının belirlenmesi için Battese ve Coelli (1992) çalışmasına benzer şekilde hipotez testleri uygulanmıştır. Farklı dağılımlardan hangisinin kullanılacağı, kısıtlanmamış model karşısında diğer modellerin sıfır hipotezinde yer alması suretiyle yapılan olabilirlik oran (LR) testi sonuçlarına göre kesikli-normal modelin kullanılmasının daha uygun olduğu sonucuna ulaşılmıştır. ${ }^{2}$ Ayrıca, eğer $u_{i}$ ve vi' nin olasılık dağılım fonksiyonları benzer şekillerde olursa etkinsizlik etkilerini istatistiksel gürültüden ayırt etmek daha zor olacaktır (Coelli vd., 2005: 252). Bu sebeplerle çalışmada kesikli-normal model kullanılmıştır.

Sonuç olarak etkinlik skorlarının hesaplanmasında kullanılan modelin tahmini aşağıdaki şekildedir.

$$
\ln \left(\mathrm{SAT}_{\mathrm{it}}\right)=-0,206+0,873 \ln \left(\mathrm{SMM}_{\mathrm{it}}\right)+0,134 \ln \left(\mathrm{FG}_{\mathrm{it}}\right)+0,049 \ln \left(\mathrm{OZS}_{\mathrm{it}}\right)
$$

Değişkenler arasındaki ilişki incelendiğinde çıktı değişkeni ile girdi değişkenleri arasında pozitif yönlü ilişki olduğu görülmüştür. Modelde teknik etkinsizlik varlığına ilişkin test yapmak için Coelli vd. (2005) tarafından önerildiği şekilde "Likelihood Ratio (LR) Test" kullanılmıştır. Bu durumda eğer LR test istatistiği, 0,05 anlamlılık düzeyinde 3 kısıtlamalı Kodde Palm (1986) tablo değeri olan 7,045'i geçiyorsa sıfır hipotezi H0: $\gamma=0$, reddedilmelidir. Test istatistiği aşağıdaki şekilde hesaplanmıştır.

$$
\mathrm{LR}=-2[670,05-954,47)]=568,84
$$

Hesaplanan LR değeri 7,045 değerinden büyük olduğu için $\mathrm{H}_{0}$ reddedilir. Sonuç olarak modelde istatistiksel olarak anlamlı bir teknik etkinsizlik bulunmaktadır. Modelin gamma değeri $\left(\gamma=\sigma_{u}^{2} / \sigma^{2}\right) 0,803^{\prime}$ tür. Bu değere göre birleşik hata terimindeki varyansın büyük bölümü etkinsizlik bileşeninden kaynaklanmaktadır. Yani birleşik hata teriminin varyansının \%80,3'ü etkinsizlik bileşeni $\mathrm{U}_{\mathrm{i}}$ 'den geri kalan \%29,7'si $\mathrm{V}_{\mathrm{i}}$ 'den kaynaklanmaktadır. Ayrıca, hesaplanan $\eta$ parametresi 0,05 anlamlılık seviyesinde anlamlı olup, negatiftir. $\mathrm{Bu}$ durum firmaların etkinlik skorlarının yıllar içinde azaldığını göstermektedir.

\subsection{Portföylerin Olușturulması ve Portföy Getirilerinin Hesaplanması}

Etkinlik skorlarının portföy getirisi üzerindeki etkisi incelenmek istendiği için Chan ve Faff'ın (2005) likiditeyi kullanarak uyguladığı portföy oluşturma yöntemi, likidite yerine etkinlik skorları kullanılarak uygulanmıştır.

Çalışmada varlıkların fiyatlaması incelendiği için varlıkların fiyatlamasında rol oynayan yatırımcıların değişkenlere ilişkin verilere sahip oldukları ve buna göre tepki verdikleri düşünülmektedir. $\mathrm{Bu}$ nedenle yatırımcıların portföy oluşturma tarihinde ilgili muhasebe verilerini bilmeleri gerekmektedir. Muhasebe verilerinin açıklayacakları getirilerden önce bilinmesinden emin olmak için t-1 yılının yılsonu muhasebe verilerinin $t$ yılının Temmuz ayından $t+1$ yılının Haziran ayına kadar olan getiriler ile eşleşmesi gerekmektedir (Fama ve French, 1992: 429). Yani yatırımcıların muhasebe verilerini öğrenip

\footnotetext{
${ }^{2}$ Detaylı bilgi için bkz: Balkan (2016).
} 
buna göre tepki vermelerinin Temmuz ayını bulacağı düşüncesi vurgulanmaktadır. Bu nedenle portföyler her $\mathrm{t}$ yılının Haziran ayında yeniden oluşturulmuştur. Fama ve French(1996) hem eşit ağırlıklı hem de değer ağırlıklı yaklaşımın analizde kullanılabileceğini belirtmiş olsa da, örneklemde az sayıda firma olması nedeniyle büyük firmaların getiri oranlarında baskın rol oynamasını engellemek amacıyla portöylere ait getiriler portföylere dahil olan hisse senetlerinin eşit ağırlıklı getirileri alınarak hesaplanmıştır. Getiriler aylık olup 2005 yılı Temmuz ayından 2015 yılı Haziran ayına kadar hesaplanmıştır.

Firma büyüklügüne göre portföy oluşturma aşamasında Fama ve French'in (1993, 1996) uyguladığı yönteme benzer bir yöntem izlenmiştir. Firma büyüklüğü için firmaların piyasa değerleri kullanılmıştır. Piyasa değeri, şirketin dolanımdaki hisse senedi sayısı ile hisse fiyatının çarpımı ile ulaşılan bir kavramdır. Portföyler Haziran ayında oluşturulduğu için hisse senetlerinin piyasa değeri olarak her yıl için Haziran ayı piyasa değerleri alınmıştır. Hisse senetleri Haziran ayı piyasa değerlerine göre büyükten küçüğe sıralanıp, piyasa değeri medyan değere eşit veya altında olan hisse senetleri küçük (S) portföy grubuna dahil edilmiş, piyasa değeri medyan değerin üzerinde olan hisse senetleri büyük (B) portföy grubuna dahil edilmiştir.

Defter değeri/Piyasa değeri (DD/PD) oranına göre portföy oluşturulması aşamasında her şirket için t-1 yılının özsermayesinin t-1 yılının piyasa değerine bölünmesiyle elde edilen DD/PD oranları, $t$ yılının Temmuz ayından başlayıp $t+1$ yılının Haziran ayına kadar devam eden dönem için portföylerin oluşturulmasında kullanılmıştır. Tüm hisse senetleri ait oldukları şirketlerin t-1 y1lı DD/PD oranlarına göre küçükten büyüğe sıralanıp DD/PD oranı medyan değerin altında olan hisse senetleri düşük (L) portföy grubuna dahil edilmiş, DD/PD oranı medyan değere eşit veya üzerinde olan hisse senetleri yüksek $(\mathrm{H})$ portföy grubuna dahil edilmiştir.

Etkinlik skorlarına göre oluşturulan portföylerde ise $\mathrm{DD} / \mathrm{PD}$ oranına göre oluşturulan portföylerdeki yöntem uygulanmıştır. Tüm hisse senetleri t-1 yılı etkinlik skorlarına göre sıralanıp, etkinlik skorları medyan değerin altında olan hisse senetleri etkinliği düşük (I) portföy grubuna dahil edilmiş, etkinlik skorları medyan değere eşit veya daha yüksek olan hisse senetleri ise etkinliği yüksek (E) portföy grubuna dahil edilmiştir.

Fama ve French (1993) hisse senetlerini DD/PD oranlarına göre siralayarak en yüksek $\mathrm{DD} / \mathrm{PD}$ oranlı $\% 30$, orta seviyede $\mathrm{DD} / \mathrm{PD}$ oranlı $\% 40$ ve en düşük $\mathrm{DD} / \mathrm{PD}$ oranlı $\% 30$ şeklinde üç gruba ayırmasına rağmen bu bölünmelerin keyfi olduğunu ve alternatifleri araştırmadıklarını belirtmişlerdir. Ammann ve Steiner (2008) büyüklük (Piyasa değeri), değer (DD/PD oranı) ve momentumu kullandığ çalışmasında $3 \times 3 \times 3$ şeklinde 27 portföy yerine, $2 \times 2 \times 2$ şeklinde 8 portföy oluşturmuştur. Buna sebep olarak ise İsviçre'deki hisse senedi sayıs 27 adet portföy oluşturmak için çok az olduğundan, $3 \times 3 \times 3$ şeklinde portföy oluşturulmas 1 durumunda bazı portföylerin boş kaldığını ve bu gruplamanın faktör oluştururken sadece en üst ve en alt grubu dahil etmesi nedeniyle tüm hisselerin portföylere dahil edilememesini göstermiştir. Bu çalışmaya konu olan firma sayısı düşük olduğu için, hisseler benzer şekilde

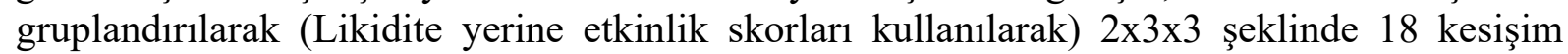
portföyü ya da $3 \times 3 \times 3$ şeklinde 27 kesişim portföyü oluşturulduğunda bazı yıllarda bazı portföylerin boş kaldığ 1 görülmüştür. Bu nedenle Ammann ve Steiner'in (2008) yönteminden esinlenerek her yıl için firma büyüklügü ile ilişkili iki grup, DD/PD oranı ile ilişkili iki grup ve etkinlik skorları ile ilişskili iki grubun kesişiminden oluşan sekiz portföy kesişim portföyleri olarak oluşturulmuştur. Söz konusu kesişim portföyleri aşağıdaki şekilde ifade edilebilir.

SHE: Bu portföyde firma büyüklüğü açısından küçük, yüksek DD/PD oranına sahip ve etkinliği yüksek firmalar bulunmaktadır. 
SHI: Bu portföyde firma büyüklüğü açısından küçük, yüksek DD/PD oranına sahip ve etkinliği düşük firmalar bulunmaktadır.

SLE: Bu portföyde firma büyüklüğü açısından küçük, düşük DD/PD oranına sahip ve etkinliği yüksek firmalar bulunmaktadır.

SLI: Bu portföyde firma büyüklüğü açısından küçük, düşük DD/PD oranına sahip ve etkinliği düşük firmalar bulunmaktadır.

BHE: $\mathrm{Bu}$ portföyde firma büyüklüğü açısından büyük, yüksek DD/PD oranına sahip ve etkinliği yüksek firmalar bulunmaktadır.

BHI: Bu portföyde firma büyüklüğü açısından büyük, yüksek DD/PD oranına sahip ve etkinliği düşük firmalar bulunmaktadır.

BLE: Bu portföyde firma büyüklüğü açısından büyük, düşük DD/PD oranına sahip ve etkinliği yüksek firmalar bulunmaktadır.

BLI: Bu portföyde firma büyüklüğü açısından büyük, düşük DD/PD oranına sahip ve etkinliği düşük firmalar bulunmaktadır.

Kesişim portföylerinin getirileri eşit ağırlıklı olarak hesaplanmıştır. Sekiz adet kesişim portföyünün her $\mathrm{t}$ yllı Temmuz ayından $\mathrm{t}+1$ yılı Haziran ayına kadar (Haziran ayı dahil) hesaplanmış, her $\mathrm{t}+1$ yılı Haziran ayında portföyler yeniden oluşturulmuştur.

Getirilerin hesaplanmasının t yılının Temmuz ayında başlamasının nedeni t-1 yılı defter değerinin bilindiğinden emin olmak içindir (Fama ve French, 1995: 134). Tablo 3'e göre ortalama getirisi en fazla olan kesişim portföyü SLE portföyüdür. Ortalama getirisi en düşük olan kesişim portföyü ise SLI portföyüdür. Standart sapması en yüksek olan portföy SLE portföyü iken en düşük olan portföy BLI portföyüdür.

Tablo 3. Kesişim Portföyleri Getirilerine İlişkin Veriler

\begin{tabular}{|l|c|c|c|c|c|c|c|c|}
\hline & SHE & SHI & SLE & SLI & BHE & BHI & BLE & BLI \\
\hline Ortalama & $2,66 \%$ & $2,13 \%$ & $2,74 \%$ & $1,35 \%$ & $2,54 \%$ & $1,99 \%$ & $1,68 \%$ & $1,69 \%$ \\
\hline Medyan & $2,21 \%$ & $3,02 \%$ & $2,48 \%$ & $0,38 \%$ & $2,20 \%$ & $2,50 \%$ & $1,93 \%$ & $2,07 \%$ \\
\hline Maksimum & $29,49 \%$ & $23,62 \%$ & $90,80 \%$ & $46,04 \%$ & $32,40 \%$ & $22,21 \%$ & $22,67 \%$ & $18,82 \%$ \\
\hline Minimum & $-26,15 \%$ & $-24,38 \%$ & $-26,96 \%$ & $-30,05 \%$ & $-27,75 \%$ & $-24,52 \%$ & $-29,77 \%$ & $-28,90 \%$ \\
\hline Standart Sapma & 0,0892 & 0,0865 & 0,1254 & 0,1102 & 0,0957 & 0,0802 & 0,0810 & 0,0786 \\
\hline
\end{tabular}

\subsection{Faktörlerin Oluşturulması ve Faktör Getirilerinin Hesaplanması}

Fama ve French $(1993,1996)$ tarafindan uygulanan portföy oluşturma yöntemi kullanılarak tüm hisse senetlerinden piyasa değeri ile DD/PD oranı kriterleri temel alınarak SMB ve HML faktörleri oluşturulmuştur. Bu çalışmada bu iki faktöre ek olarak etkinlik skorlarının etkisi de inceleneceği için yeni bir faktör olarak etkinlik skorlarının temel alındığı EMI adı verilen yeni bir faktör oluşturulmuştur.

Portföy getirilerini açılamak amacıyla (RM - RF), SMB, HML ve EMI olmak üzere dört adet risk faktörü belirlenmişsir.

Faktörlerin hesaplanmas1, Ammann ve Steiner'in (2008) momentum faktörünü Fama French üç faktörlü modeline ekleyerek yaptığı çalışmaetkinlik skorlarının modele eklenmesi şeklinde uyarlanarak yapılmıştır. Her ay için SMB faktörü, dört küçük piyasa değerli portföyün (SHE, SHI, SLE, SLI) ortalama getirisi ile dört büyük piyasa değerli portföyün (BHE, BHI, BLE, BLI) ortalama getirisi arasındaki fark olarak hesaplanmıştır. Benzer şekilde 
HML, yüksek DD/PD oranlı firmalardan oluşan dört portföyün (SHE, SHI, BHE, BHI) aylık ortalama getirisi ile düşük DD/PD oranlı firmalardan oluşan dört portföyün (SLE, SLI, BLE, BLI) aylık ortalama getirisi arasındaki fark şeklinde hesaplanmıştır. Bu çalışmada oluşturulan EMI faktörü ise etkinliği yüksek olan firmalardan oluşan dört portföyün (SHE, SLE, BHE, BLE) aylık ortalama getirisi ile etkinliği düşük firmalardan oluşan dört portföyün (SHI, SLI, BHI, BLI) aylık ortalama getirisi arasındaki fark olarak hesaplanmıştır.

Üç faktörün oluşturulmasında, her portföy diğer faktörlerin etkileri kontrol edilerek oluşturulmuştur. Böylece, her portföyün bir faktör açısından bir karşıtı bulunmaktadır. Yani diğer iki faktör açısından özelliği aynı fakat bir faktör açısından karşıt olabilen portföyler oluşturulmuştur. $\mathrm{Bu}$ sayede herhangi bir faktör diğer faktörlerin etkisini içermemektedir (Chan ve Faff, 2005: 438).

Oluşturulan bu portföylerin ve faktörlerin getirilerine ilişkin veriler Tablo 4'te gösterilmiştir. Ortalama getirisi en fazla olan portföy E ile ifade edilen etkinlik skorlarına göre yüksek skorlara sahip olan portföydür. Ortalama getirisi en düşük olan portföy ise L ile ifade edilen DD/PD oranına göre düşük orana sahip olan portföydür. Portföyler arası farktan oluşan SMB, HML ve EMI faktörlerinden ortalaması en yüksek olan EMI faktörüdür. Bu durum en fazla farkın etkinliği yüksek (E) ve etkinliği düşük (I) portföyleri arasında olduğunu göstermektedir. Böylece etkin olup olmama durumunun getiri farkına en çok neden olan unsur olduğu sonucuna ulaşılmıştır. Ayrıca, yüksek DD/PD oranına sahip hisselerden oluşan portföyler düşük $\mathrm{DD} / \mathrm{PD}$ oranına sahip hisselerden oluşan portföylere göre daha fazla getiri elde etmiştir. Bu durum incelenen hisseler için değer priminin bulunduğunu göstermektedir. Bununla birlikte tablodaki bulgular firma büyüklüğü açısından incelendiğinde görülmektedir ki, küçük firmalardan oluşan portföyler büyük firmalardan oluşan portföylere göre daha yüksek performans sergilemiştir. Yani incelenen örneklem için büyüklük etkisi bulunmaktadır.

Tablo 4. Kesişim Portföylerine Göre Oluşturulmuş Portföy Ve Faktör Getirileri

\begin{tabular}{|l|c|c|c|c|c|c|c|c|c|}
\hline & S & B & SMB & H & L & HML & E & I & EMI \\
\hline Ortalama & $2,22 \%$ & $1,97 \%$ & $0,25 \%$ & $2,33 \%$ & $1,87 \%$ & $0,46 \%$ & $2,41 \%$ & $1,79 \%$ & $0,62 \%$ \\
\hline Medyan & $2,01 \%$ & $2,65 \%$ & $-0,17 \%$ & $2,29 \%$ & $2,15 \%$ & $0,72 \%$ & $2,33 \%$ & $1,84 \%$ & $0,65 \%$ \\
\hline Maksimum & $32,74 \%$ & $17,70 \%$ & $18,69 \%$ & $18,66 \%$ & $34,00 \%$ & $6,00 \%$ & $35,73 \%$ & $23,06 \%$ & $24,68 \%$ \\
\hline Minimum & $-26,51 \%$ & $-26,36 \%$ & $-6,96 \%$ & $-24,33 \%$ & $-28,54 \%$ & $-21,22 \%$ & $-27,66 \%$ & $-25,21 \%$ & $-8,60 \%$ \\
\hline Standart Sapma & 0,0936 & 0,0775 & 0,0413 & 0,0804 & 0,0894 & 0,0329 & 0,0870 & 0,0833 & 0,0342 \\
\hline
\end{tabular}

\subsection{Modellerin Zaman Serisi Regresyonları}

Sekiz adet kesişim portföyü için bu çalışmada oluşturulan dört faktörlü model, FamaFrench üç faktörlü model ve SVFM modelleri kullanılarak zaman serisi regresyon analizleri gerçekleştirilmiştir. Tüm modellerde sekiz adet kesişim portföyüne ait getirilerin risksiz faiz oranını aşan kısmı bağımlı değişken olarak kullanılmıştır. Zaman serisi regresyon analizinde portföy getirileri olarak 2005 yılının Temmuz ayından 2015 yılının Haziran ayına kadar olan dönemi kapsayan 120 aylık getiriler alınmıştır. Regresyon analizleri Eviews programı kullanılarak yapılmıştır. 


\subsection{GRS F-Testi}

Black vd. (1972) modelde kesişim katsayısının sıfırdan farklı olduğu hipotezi eğer reddedilemiyorsa, modelin verilerle uyumlu olmadığı sonucuna ulaşılacağını belirtmiştir. Merton'a (1973) göre iyi belirlenmiş bir varlık fiyatlandırma modeli sıfirdan ayırt edilemez kesişim katsayıları oluşturacaktır (Fama ve French, 1993: 5).

Çalışmaya konu modellerdeki kesişim katsayılarının istatistiksel olarak anlamlı bir şekilde sıfırdan farklı olup olmadıklarını test etmek için analizde Gibbons, Ross ve Shanken (1989) tarafından geliştirilen GRS F-testi kullanılmıştır. GRS F-testi ile N adet zaman serisi denklemiyle tahmin edilen tüm kesişim katsayılarının sıfırdan farklı olup olmadığına dair sıfır hipotezi test edilebilmektedir. (Gökgöz, 2008: 50).

GRS F istatistiği modellerin ampirik olarak verilere uygunluğunu incelemek ve $\alpha_{i}=0$, $\forall \mathrm{i}$ hipotezini test etmek için kullanılmaktadır. Test istatistiği aşağıdaki şekildedir (Shaker ve Elgiziry, 2014: 27).

$$
G R S=\left(\frac{T}{N}\right)\left(\frac{T-N-L}{T-L-1}\right)\left[\frac{\hat{\alpha} \hat{\Sigma}^{-1} \hat{\alpha}}{1+\bar{\mu} \hat{\Omega}^{-1} \bar{\mu}}\right] \sim F(N, T-N-L)
$$

\footnotetext{
$\alpha=$ Hesaplanan kesişim katsayısının $\mathrm{N}$ x 1 boyutlu vektörü

$\hat{\Sigma}=$ Hata terimleri yansiz kovaryans matrisi

$\bar{\mu}=$ Faktör portföyleri örneklem ortalamalarının $\mathrm{L}$ x 1 boyutlu vektörü

$\widehat{\Omega}=$ Faktör portföyleri kovaryans matrisinin yansız tahmini

$\mathrm{T}=$ Gözlem sayıs

$\mathrm{N}=$ Regresyon sayıs

$\mathrm{L}=$ Regresyondaki açıklayıcı faktör sayısı
}

\section{BULGULAR}

Tablo 5 dört risk faktör portföyünün korelasyonunu göstermektedir. Pazar portföyünün fazla getirisi ile HML ve EMI faktörleri arasında negatif ilişki bulunmakta iken bu ilişki zayıftır. SMB ve HML arasında negatif ve güçlü olmayan bir ilişki bulunmaktadır. EMI'nin ise tüm diğer faktörlerle arasındaki ilişki zayıftır. Bu sebeplerle çoklu doğrusal bağlantı bulunmadığı kanaati oluşmuştur.

Tablo 5. Korelasyon Tablosu

\begin{tabular}{|l|c|c|c|c|}
\hline & RM - RF & SMB & HML & EMI \\
\hline RM - RF & 1 & 0,0865 & $-0,1052$ & $-0,0593$ \\
\hline SMB & 0,0865 & 1 & $-0,5579$ & 0,1196 \\
\hline HML & $-0,1052$ & $-0,5579$ & 1 & $-0,2536$ \\
\hline EMI & $-0,0593$ & 0,1196 & $-0,2536$ & 1 \\
\hline
\end{tabular}


Tüm modeller için sekiz adet kesişim portföyünün Temmuz 2005 - Haziran 2015 dönemine ait aylık getirileri kullanılmıştır. SVFM modeli regresyon sonuçları Tablo 6'da gösterilmektedir.

Tablo 6. SVFM Regresyon Sonuçları

\begin{tabular}{|c|c|c|c|c|}
\hline Portföy & $\alpha$ & $\beta$ & F-İstatistiği & Düzeltilmiş $\mathbf{R}^{2}$ \\
\hline SHE & $0,014^{*}$ & $0,876^{*}$ & 179,364 & 0,600 \\
\hline SHI & $0,009 * *$ & $0,843^{*}$ & 171,886 & 0,589 \\
\hline SLE & 0,015 & $0,911 *$ & 58,126 & 0,324 \\
\hline SLI & 0,001 & $0,998^{*}$ & 124,170 & 0,509 \\
\hline BHE & $0,013^{*}$ & $0,865^{*}$ & 120,801 & 0,502 \\
\hline BHI & $0,007 * *$ & $0,866^{*}$ & 309,623 & 0,722 \\
\hline BLE & 0,004 & $0,835^{*}$ & 228,374 & 0,656 \\
\hline BLI & 0,004 & $0,881 *$ & 414,306 & 0,776 \\
\hline
\end{tabular}

Oluşturulan tüm portföyler için SVFM regresyon sonuçlarına göre hesaplanan F istatistiklerine ait değerler modellerin genel olarak anlamlı olduğunu göstermektedir. Piyasa betası tüm portföyler için istatistiksel olarak anlamlı ve pozitiftir. Modeldeki $\alpha$ katsayılarının istatistiksel olarak anlamlılığı ayrı ayrı incelendiğinde, SHE ve BHE portföyleri için tahmin edilen regresyon modellerindeki $\alpha$ katsayıları hariç, diğer modellerdeki $\alpha$ katsayılarının $\% 5$ anlam düzeyinde istatistiksel olarak anlamsız olduğu gözlemlenmektedir.

Tablo 7. Fama-French Üç Faktörlü Model Regresyon Sonuçları

\begin{tabular}{|c|c|c|c|c|c|c|}
\hline Portföy & $\alpha$ & $\beta$ & $\mathbf{s}$ & h & F- İstatistiği & Düzeltilmiş $\mathbf{R}^{2}$ \\
\hline SHE & $0,008^{*}$ & $0,851^{*}$ & $1,170^{*}$ & $0,642 *$ & 162,381 & 0,803 \\
\hline SHI & 0,004 & $0,819^{*}$ & $1,043^{*}$ & $0,543^{*}$ & 127,209 & 0,761 \\
\hline SLE & $0,017^{*}$ & $0,803^{*}$ & $1,299^{*}$ & $-1,129^{*}$ & 107,225 & 0,728 \\
\hline SLI & $-0,001$ & $0,941^{*}$ & $1,030^{*}$ & $-0,252$ & 88,846 & 0,689 \\
\hline BHE & $0,012 * *$ & $0,880 *$ & $-0,097$ & 0,247 & 41,620 & 0,506 \\
\hline BHI & 0,005 & $0,863^{*}$ & $0,426^{*}$ & $0,373^{*}$ & 120,843 & 0,751 \\
\hline BLE & $0,007 * *$ & $0,806^{*}$ & 0,123 & $-0,534^{*}$ & 101,312 & 0,717 \\
\hline BLI & $0,006 * *$ & $0,865^{*}$ & 0,09 & $-0,280^{*}$ & 154,517 & 0,795 \\
\hline
\end{tabular}

Tablo 7'ye göre tüm modeller için Fama-French üç faktör regresyon modeli tahmin sonuçlarından hesaplanan $\mathrm{F}$ istatistiği değerleri modellerin genel olarak anlamlı olduğunu göstermektedir.

Piyasa betası tüm portföyler için istatistiksel olarak anlamlı ve pozitiftir. SMB faktörü katsayısı tüm küçük portföyler için istatistiksel olarak anlamlı ve pozitiftir. Büyük portföylerden ise BHI portföyü için SMB katsayısı anlamlı ve pozitiftir. Diğer büyük portföyler için SMB katsayısı istatistiksel olarak anlamlı değildir. HML katsayısı SLI ve BHE portföyleri haricindeki tüm portföyler için istatistiksel olarak anlamlı olup, DD/PD oranı yüksek olan portföylerde pozitif, DD/PD oranı düşük olan portföylerde negatiftir. 
Modeldeki $\alpha$ katsayılarının istatistiksel olarak anlamlllı̆̆ ayrı ayrı incelendiğinde, SHE ve SLE portföyleri için tahmin edilen regresyon modellerindeki $\alpha$ katsayıları hariç, diğer modellerdeki $\alpha$ katsayılarının $\% 5$ anlam düzeyinde istatistiksel olarak anlamsız olduğu gözlemlenmektedir.

Tablo 8. EMI Faktörü Eklenmiş 4 Faktörlü Model Sonuçları

\begin{tabular}{|l|c|c|c|c|c|r|c|}
\hline Portföy & $\boldsymbol{\alpha}$ & $\boldsymbol{\beta}$ & $\mathbf{s}$ & $\mathbf{h}$ & $\mathbf{f}$ & F- İstatistiği & Düzeltilmiş $\mathbf{R}^{2}$ \\
\hline SHE & $0,006^{* *}$ & $0,861^{*}$ & $1,176^{*}$ & $0,721^{*}$ & $0,273^{*}$ & 128,989 & 0,811 \\
\hline SHI & 0,003 & $0,823^{*}$ & $1,045^{*}$ & $0,568^{*}$ & 0,086 & 95,146 & 0,760 \\
\hline SLE & 0,006 & $0,856^{*}$ & $1,332^{*}$ & $-0,713^{*}$ & $1,437^{*}$ & 204,013 & 0,872 \\
\hline SLI & 0,004 & $0,920^{*}$ & $1,017^{*}$ & $-0,414^{*}$ & $-0,561^{*}$ & 75,658 & 0,715 \\
\hline BHE & 0,003 & $0,921^{*}$ & $-0,071$ & $0,568^{*}$ & $1,110^{*}$ & 56,276 & 0,650 \\
\hline BHI & $0,006^{* *}$ & $0,855^{*}$ & $0,420^{*}$ & $0,305^{*}$ & $-0,234^{*}$ & 94,470 & 0,759 \\
\hline BLE & 0,004 & $0,821^{*}$ & 0,132 & $-0,414^{*}$ & $0,415^{*}$ & 87,121 & 0,743 \\
\hline BLI & $0,006^{* *}$ & $0,863^{*}$ & 0,088 & $-0,297^{*}$ & $-0,057$ & 115,292 & 0,793 \\
\hline
\end{tabular}

Tablo 8 incelendiğinde 4 faktörlü regresyon modeli tahmininden sonra yapılan $F$ testlerinin sonuçları Fama-French üç faktörlü model ve SVFM modellerinde olduğu gibi kurulan modellerin genel olarak anlamlı olduğunu göstermiştir.

Piyasa betası tüm portföyler için istatistiksel olarak anlamlı ve pozitiftir. SMB faktörü katsayısı dört faktörlü modelde Fama-French üç faktörlü model ile benzer sonuçlara sahip olup, tüm küçük portföyler için istatistiksel olarak anlamlı ve pozitiftir. Büyük portföylerden ise BHI portföyü için SMB katsayısı anlamlı ve pozitiftir. Diğer büyük portföyler için SMB katsayısı istatistiksel olarak anlamlı değildir. BHE portföyü için SMB katsayısı negatif bulunmuştur. HML katsayısı tüm portföyler için istatistiksel olarak anlamlı olup, DD/PD oranı yüksek olan portföylerde pozitif, DD/PD oranı düşük olan portföylerde negatiftir. EMI faktörünün katsayısı SHI ve BLI portföyleri haricindeki altı portföy için istatistiksel olarak anlamlı bulunmuştur. Söz konusu altı portföyden etkinliği yüksek olan portföyler için etkinlik faktörü katsayısı pozitif olup, etkinliği düşük portföyler için bu katsayı negatiftir.

Her üç model için oluşturulan regresyon sonuçlarına göre piyasa betası istatistiksel olarak anlamlı olup, bu katsayının t istatistikleri diğer faktörlerden daha yüksektir. Bu durum hisse getirilerindeki değişimleri açıklamada en önemli faktörün piyasa betası olduğunun göstergesidir (Canbaş ve Arığlu, 2008: 88).

Düzeltilmiş $\mathrm{R}^{2}$, karşılaştırma için $\mathrm{R}^{2}$ 'den daha iyi bir ölçüdür (Gujarati ve Porter, 2012: 493). Bu sebeple regresyon sonuçlarına ait tablolarda düzeltilmiş $\mathrm{R}^{2}$ ye yer verilmiş ve yorumlar bu değer üzerine yapılmıştır. Dört faktörlü modelin düzeltilmiş $\mathrm{R}^{2}$ değerleri ortalaması 0,763 olup, modelin bağımlı değişkeni açıklama oranı incelenen modeller arasındaki en yüksek değerdir. Sonuç olarak $\mathrm{R}^{2}$ değerleri göstermektedir ki, dört faktör her portföy için risksiz faiz oranını aşan aylık getirilerinin büyük kısmını açıklamaktadır. Sistematik risk faktörleri olan RM-RF, SMB, HML ve EMI'nın katsayılarının SHE, SLE, SLI ve BHI portföylerinde anlamlı olduğu görülmektedir. Ayrıca, sonuçlarda görülmektedir ki; EMI katsayısının istatistiksel olarak anlamlı olduğu modellerde dört faktörlü modelin düzeltilmiş $\mathrm{R}^{2}$ değeri Fama French üç faktörlü modele göre artış göstermiştir. EMI 
katsayısının anlamlı olmadığı portföyler için (SHI ve BLI) 4 faktörlü modelin düzeltilmiş $\mathrm{R}^{2}$ değeri, üç faktörlü modelin düzeltilmiş $\mathrm{R}^{2}$ değerine göre düşüktür. Yani 6 portföyün getirileri açıklama gücü dört faktörlü model ile artmıştır.

Fama ve French (1993) getirileri iyi bir şekilde açıklayan fiyatlama modellerindeki sabit terimlerin istatistiksel olarak anlamlı olmaması yani sıfıra yakın olması gerektiğini belirtmiştir. Bu noktadan hareketle, sabit terim sıfıra ne kadar yakın ise modelin risksiz faiz oranını aşan portföy getirilerini o kadar iyi açıkladığı çıkarımı yapılmıştır. Gibbons, Ross, Shanken (1989) tarafından geliştirilen GRS F-istatistiği, zaman serisi regresyonları bağlamında yüksek bulunduğu takdirde, modelin etkinliği azalmaktadır. GRS F testi, bütün zaman serisi regresyonlarının her portföy için sabit terimlerinin sıfır olup olmadığını test etmek için kullanılmıştır. Bu durumda sıfır hipotezi ve alternatif hipotez aşağıdaki şekildedir.

\section{$H_{0}$ : Modelden elde edilen tüm sabit terimler sifira eşittir $\left(\alpha_{i}=0, \forall_{i}\right)$.}

\section{$H_{1}$ : Modelden elde edilen tüm sabit terimler sıfıra eşit değildir.}

Bütün zaman serisi regresyonlarında her portföy için $\alpha$ katsayılarının aynı anda sıfırdan farklı olup olmadığını incelemek üzere her üç modelde de GRS F testi uygulanmış ve $\alpha$ katsayılarının aynı anda sıfıra eşit olduğunu ifade eden sıfır hipotezi incelenmiştir. GRS F testi sonuçları aşağıdaki tabloda gösterilmektedir.

Tablo 9. GRS F Testi Sonuçları

\begin{tabular}{|l|c|c|}
\hline Modeller & GRS Test & P-değeri \\
\hline SVFM & 2,0219 & 0,0501 \\
\hline Fama-French üç faktörlü model & 1,3525 & 0,2257 \\
\hline Dört faktörlü model & 0,4808 & 0,8675 \\
\hline
\end{tabular}

Tablo 9'dan anlaşılacağı üzere SVFM için $\alpha$ katsayılarının aynı anda sıfira eşit olduğunu ifade eden sıfır hipotezi reddedilememiştir $(p=0,0501>\alpha=0,05)$. Fama-French üç faktörlü model için de aynı durum söz konusudur $(p=0,2257>\alpha=0,05)$. Fakat $p$ değeri SVFM'ye göre yüksektir. GRS F testi sonuçlarına göre modellerin hepsi için tüm $\alpha$ katsayıları sıfırdan farklı değildir. Analize tabi tutulan üç model arasında en yüksek p değerine ve en düşük GRS $F$ istatistiğine sahip olan dört faktörlü model için de $(p=0,8675>\alpha=0,05) \alpha$ katsayılarının aynı anda sıfıra eşit olduğunu ifade eden sıfır hipotezi reddedilememiştir. Çalışmada kullanılan üç model bu yönden incelendiğinde görülmektedir ki; GRS-F istatistiği değerlerine göre en etkin model dört faktörlü model, etkinliği en az olan model ise SVFM modelidir. $\mathrm{Bu}$ durum etkinlik faktörü olan EMI faktörünün varlık fiyatlama modeline dahil edilmesi yönünde bir sonuç ortaya koymuştur. Yani SVFM'ye SMB ve HML faktörleri eklenerek elde edilen Fama French üç faktörlü modeli SVFM'ye göre daha etkin hale gelmiş, Fama French üç Faktörlü modele EMI faktörünün eklenmesiyle elde edilen dört faktörlü model ise Fama French üç faktörlü modele göre daha etkin bir model olarak ortaya çıkmıştır. Dört faktörlü modelde tüm portföyler için kesişim katsayısının sıfır olduğu hipotezi reddedilemediğinden ve dört faktörlü modelin GRS-F istatistiği analiz edilen diğer modellere göre daha düşük olduğundan kullanılan dört faktörün de portföylerin risksiz faiz oranını aşan getirilerini açıklamak için gerekli olduğu sonucuna ulaşılmıştır. 
Dört faktörlü modelin regresyon sonuçlarına göre küçük piyasa değerine sahip firmaların bulunduğu portföyler için (SHE, SHI, SLE ve SLI), SMB eğimlerinin pozitif ve yüksek olduğu, büyük piyasa değerine sahip firma portföylerinin ise nispeten düşük SMB eğimine sahip olduğu bulgusuna ulaşılmıştır. Bu bulgu firma büyüklüğü etkisine işaret etmektedir. Söz konusu durum, küçük piyasa değerine sahip firmaların oluşturduğu portföylerde firma büyüklüğü etkisinin daha fazla olduğunu göstermektedir. Ayrıca yüksek DD/PD oranına sahip firmalar portföyünün (SHE, SHI, BHE ve BHI), HML eğimlerinin pozitif olması, düşük DD/PD oranına sahip firmalar portföyünün (SLE, SLI, BLE ve BLI) de negatif HML eğimine sahip olması değer etkisinin varlığını göstermektedir. Bu etki, yüksek $\mathrm{DD} / \mathrm{PD}$ oranına sahip firmaların oluşturduğu portföylerde değer etkisinin pozitif yönlü, düşük $\mathrm{DD} / \mathrm{PD}$ oranına sahip firmalardan oluşan portföylerde değer etkisinin negatif yönlü olduğunu göstermektedir. Küçük piyasa değerine sahip portföylerde etkinlik etkisinin yönü konusunda net bir bulgu olmasa da büyük piyasa değerine sahip portföyler için etkinlik etkisinin, etkinliği yüksek firmaların bulunduğu portföyler için pozitif yönlü, etkinliği düşük firmaların bulunduğu portföyler için negatif yönlü olduğu görülmektedir.

\section{SONUÇ}

Bu çalışmada, firmaların faaliyetlerini uyguladıkları sürede gösterdikleri performansın yani etkinliklerinin, yatırımcılar tarafından ne şekilde değerlendirildiği araştırılmıştır. Bunun için etkinlik skorlarının finansal varlıkların fiyatlandırılmasındaki rolü, Borsa İstanbul'da işlem gören sanayi firmalarına ait hisse senetlerini analize tabi tutarak incelenmiş̧tir. Sanayi firmalarını temsil etmek üzere verilerin alındığı tarihte Borsa İstanbul sınai endekste bulunan firmalardan verileri analize uygun ve yeterli olanlar örneklem olarak seçilmiştir.

Çalışmada elde edilen değerlere göre en etkin modelin dört faktörlü model, etkinliği en az olan modelin ise SVFM modeli olduğu ortaya çıkmıştır. Bu durum etkinlik faktörü olan EMI faktörünün varlık fiyatlama modeline dahil edilmesi yönünde bir sonuç ortaya koymuştur. Yani SVFM'ye SMB ve HML faktörleri eklenerek elde edilen Fama French ü̧̈ faktörlü modeli SVFM'ye göre daha etkin hale gelmiş, Fama French üç Faktörlü modele EMI faktörünün eklenmesiyle elde edilen dört faktörlü model ise Fama French üç faktörlü modele göre daha etkin bir model olarak ortaya çıkmıştır. Sonuç olarak SVFM, Fama-French üç faktörlü model ve bu çalışmada oluşturulan dört faktörlü modelin örneklemde yer alan sanayi firmaları için geçerli olduğu ve ayrıca piyasa riskinin yanında firma büyüklüğü, DD/PD oranı ve etkinlik faktörlerinin hisse senedi getirilerini etkileyen anlamlı risk faktörleri olduğu ve dört faktöre ait risk primlerinin piyasa tarafından fiyatlandırıldığı tespit edilmiştir. Bu sebeple bulguların sanayi firmaları için, etkinlik faktörünü içeren dört faktörlü modeli desteklediği söylenebilmektedir.

Çalışmada oluşturulan faktörlerden SMB ve HML faktörü ortalama getirileri ile EMI faktörü ortalama getirileri karşılaş̧ırıldığında EMI faktörü ortalama getirilerinin daha fazla olduğu görülmektedir. Yani etkin firmalar ile etkin olmayan firmalar arasındaki getiri fark1, hem küçük firmalar ile büyük firmalar arasındaki getiri farkından, hem de DD/PD oranı yüksek olan firmalar ile $\mathrm{DD} / \mathrm{PD}$ oranı düşük olan firmalar arasındaki getiri farkından fazladır. $\mathrm{Bu}$ sonuç etkinlik etkisinin diğer faktör etkilerine göre daha fazla olduğunu göstermektedir. Çalışmada incelenen etkinlik yatırım stratejisine göre, analize konu olan dönem için, yatırımcılar içinde bulunulan yıldan önceki yılda etkinliği yüksek olan sanayi firmalarına yatırım yaparak daha fazla kar elde etme olanağına sahip olmuşlardır. 
Etkinliğin getiri üzerindeki etkisinin bulunduğu savının bu çalışma sonuçlarınca desteklenmesinin ileride farklı sektörler ve farklı dönemler için yapılacak çalışmalara 1 şık tutması açısından önemli olduğu değerlendirilmektedir. Bununla birlikte, diğer sektörler için yapılacak benzer çalışmalar ile etkinliğin finansal varlık getirisindeki rolü konusuna önemli katkılar sağlanabileceği düşünülmektedir.

\section{KAYNAKLAR}

Akyüz, Y. - Yıldız, F. - Kaya, Z. (2013), "Veri Zarflama Analizi (Vza) ve Malmquist Endeksi ile Toplam Faktör Verimlilik Ölçümü: BİST’te İşlem Gören Mevduat Bankaları Üzerine Bir Uygulama”, Atatürk Üniversitesi İktisadi ve İdari Bilimler Dergisi, 27(4), ss. $110-130$.

Ammann, M. - Steiner, M. (2008), "Risk Factors for the Swiss Stock Market", Swiss Journal of Economics and Statistics, 144(1), pp. 1-35.

Aygören, H. - Yeşilyurt, M. E. (2011), "Impact of Firm Attributes on the Efficiency of Brokerage Houses”, BDDK Bankacılık ve Finansal Piyasalar Dergisi, 5(2), pp. 155 177.

Bakırcı, F. (2006), "Sektörel Bazda Bir Etkinlik Ölçümü: VZA ile Bir Analiz”, Atatürk Üniversitesi İktisadi ve İdari Bilimler Dergisi, 20(2), ss. 199-217.

Balkan, E. (2016), "Finansal Varlıkların Fiyatlandırılmasında Etkinlik Skorlarının Rolü”, Pamukkale Üniversitesi, Sosyal Bilimler Enstitüsü, Yayımlanmamış doktora tezi, Denizli.

Battese, G. E. - Coelli, T. J. (1992), "Frontier Production Functions, Technical Efficiency and Panel Data: With Application to Paddy Farmers in India", Journal of Productivity Analysis, 3, pp. 153-169.

Bayyurt, N. - Sagbansua, L. (2007). "Determining The Efficiency of Concrete Companies Ranked in Top 1000 Manufacturing Firms Trading in ISE: A Multi-Criteria Data Envelopment Analysis Model”, İ.Ü. İşletme Fakültesi İşletme Dergisi, 36(2), pp. 5471.

Black, F., Jensen - M. C. - Scholes, M. (1972), "The Capital Asset Pricing Model: Some Empirical Tests", In M. C. Jensen (Ed.), Studies in Theory of Capital Markets, pp. 79121, Praeger, New York.

Canbaş, S. - Arığlu, E. (2008), "Testing the Three Factor Model of Fama and French: Evidence from Turkey”, Çukurova Üniversitesi Sosyal Bilimler Enstitüsü Dergisi, 17(3), pp. 79-92.

Carhart, M. M. (1997), “On Persistence in Mutual Fund Performance”, Journal of Finance, 52 , pp. 57-82.

Castiglione, C. - Infante, D. (2014), "ICTs and Time-Span in Technical Efficiency Gains. A Stochastic Frontier Approach Over a Panel of Italian Manufacturing Firms", Economic Modelling, 41, pp. 55-65.

Chan, H. W. - Faff, R. W. (2005), "Asset Pricing and the Illiquidity Premium”, The Financial Review, 40, pp. 429-458.

Coelli, T. J. - Rao, D. S. P. - O’Donnell, C. J. - Battese, G. E. (2005). “An Introduction to Efficiency and Productivity Analysis", Second Edition, Springer, New York.

Daraio, C. - Simar, L. (2007), “Advanced Robust and Nonparametric Methods In Efficiency Analysis: Methodology and Applications", Springer, New York. 
Ertuğrul, İ. - Tuş Işık, A. (2008). "Işsletmelerin VZA ile Mali Tablolarına Dayalı Etkinlik Ölçümü: Metal Ana Sanayiinde Bir Uygulama”, Afyon Kocatepe Üniversitesi, İ.İ.B.F. Dergisi, 10(1), ss. 201-217.

Fama, E. F. - French, K. R. (1992), "The Cross-Section of Expected Stock Returns", The Journal of Finance, 47(2), pp. 427-465.

Fama, E. F. - French, K. R. (1993), "Common Risk Factors in The Returns on Stocks and Bonds", Journal of Financial Economics, 33, pp. 3-56.

Fama, E.F. - French, K.R. (1995), "Size and Book-to-Market Factors in Earnings and Returns", The Journal Of Finance, 50(1), pp. 131-155.

Fama, E. F. - French, K. R. (1996), "Multifactor Explanations of Asset Pricing Anomalies", The Journal of Finance, 51(1), pp. 55-84.

Fama, E. F. - French, K. R. (2015), "A Five-Factor Asset Pricing Model", Journal of Financial Economics, 116, pp. 1-22.

Gibbons, M.R. - Ross, S.A. - Shanken, J. (1989), "A Test of the Efficiency of a Given Portfolio", Econometrica, 57(5), pp. 1121-1152.

Gökgöz, F. (2008), "Üç Faktörlü Varlık Fiyatlandırma Modelinin İstanbul Menkul Kıymetler Borsasında Uygulanabilirliği”, Ankara Üniversitesi SBF Dergisi, 63(2), ss. 43-64.

Gujarati, D.N. - Porter, D.C. (2012), "Temel Ekonometri”, Beşinci Basımdan Çeviri, Literatür Yayıncilik, İstanbul.

Kayalı, C. A. (2009), "2007 Yılı Tekstil İşletmelerinin Finansal Karlılık Açısından Etkinliklerinin Değerlendirmesi”, Tekstil ve Konfeksiyon Dergisi, 19(1), ss. 3-8.

Kodde, D. A. - Palm, F. C. (1986), "Wald Criteria for Jointly Testing Equality and Inequality Restrictions", Econometrica, 54(5), pp. 1243-1248.

Lintner, J. (1965), "The Valuation of Risk Assets and the Selection of Risky Investments in Stock Portfolios and Capital Budgets", The Review of Economics and Statistics, 47(1), pp. 13-37.

Markowitz, H. (1952), "Portfolio Selection”, The Journal of Finance, 7(1), pp. 77-91.

Merton, R. C. (1973), “An Intertemporal Capital Asset Pricing Model”, Econometrica, 41(5), pp. 867-887.

Mossin, J. (1966). "Equilibrium in a Capital Asset Market", Econometrica, 34(4), pp. 768783.

Nguyen, D. - Puri, T. N. (2009), "Systematic Liquidity, Characteristic Liquidity And Asset Pricing", Applied Financial Economics, 19(11), pp. 853-868.

Nguyen, G. X. - Swanson, P. E. (2009), "Firm Characteristics, Relative Efficiency and Equity Returns", Journal of Financial and Quantitative Analysis, 44(1), pp. 213-36.

Özdağoğlu, A. (2015), "Bilişim Sektöründeki Şirketlerin Etkinliklerinin Veri Zarflama Analizi ile Değerlendirilmesi”, Yönetim ve Ekonomi: Celal Bayar Üniversitesi İktisadi ve İdari Bilimler Fakültesi Dergisi, 22(2), ss. 331-340.

Pastor, L. - Stambaugh, R. F. (2003), "Liquidity Risk and Expected Stock Returns". Journal of Political Economy, 111(3), pp. 642-685.

Radam, A. - Yacob, M.R. - Muslim, H.F.M. (2010). "Technical Efficiency of the Malaysian Wooden Furniture Industry: A Stochastic Frontier Production Approach", International Business Research, 3(3), pp. 10-15.

Rahim, R.A. - Nor, A.H.S.M. (2006), "A Comparison Between Fama and French Model and Liquidity-Based Three-Factor Models in Predicting the Portfolio Returns", Asian Academy of Management Journal of Accounting and Finance, 2(2), pp. 43-60. 
Ross, S. A. - Westerfield, R. W. - Jordan, B. D. (2012), "Fundamentals of Corporate Finance", Tenth Edition, McGraw-Hill Irwin, New York.

Sevilengül, O. (2005), "Genel Muhasebe", 12. Bask1, Gazi Kitabevi, Ankara.

Shaker, M.A. - Elgiziry, K. (2014), "Comparisons of Asset Pricing Models in the Egyptian Stock Market", Accounting and Finance Research, 3(4), pp. 24-30.

Sharpe, W. F. (1964), "Capital Asset Prices: A Theory of Market Equilibrium under Conditions of Risk. The Journal of Finance", 19(3), pp. 425-442.

Ulucan, A. (2002), "ISO 500 Şirketlerinin Etkinliklerinin Ölçülmesinde Veri Zarflama Analizi Yaklaşımı: Farklı Girdi Çıktı Bileşenleri ve Ölçeğe Göre Getiri Yaklaşımları ile Değerlendirmeler", Ankara Üniversitesi SBF Dergisi, 57(2), ss. 185-202.

Ünlü, U. (2013), "Evidence to Support Multifactor Asset Pricing Models: The Case of the Istanbul Stock Exchange”, Asian Journal of Finance \& Accounting, 5(1), pp. 197-208. 